\title{
Long-term summer sunshine/moisture stress reconstruction from tree-ring widths from Bosnia and Herzegovina
}

\author{
S. Poljanšek ${ }^{1}$, A. Ceglar ${ }^{2}$, and T. Levanič ${ }^{1}$ \\ ${ }^{1}$ Slovenian Forestry Institute, Večna pot 2, 1000 Ljubljana, Slovenia \\ ${ }^{2}$ Biotechnical Faculty, Department of Agronomy, Chair of Agrometeorology, Jamnikarjeva 101, 1000 Ljubljana, Slovenia
}

Correspondence to: T. Levanič (tom.levanic@gozdis.si)

Received: 13 August 2012 - Published in Clim. Past Discuss.: 10 September 2012

Revised: 11 December 2012 - Accepted: 12 December 2012 - Published: 11 January 2013

\begin{abstract}
We present the first summer sunshine reconstruction from tree-ring data for the western part of the Balkan Peninsula. Summer sunshine is tightly connected with moisture stress in trees, because the moisture stress and therefore the width of annual tree-rings is under the influence of the direct and interactive effects of sunshine duration (temperature, precipitation, cloud cover and evapotranspiration). The reconstruction is based on a calibrated z-scored mean chronology, calculated from tree-ring width measurements from 7 representative black pine (Pinus nigra Arnold) sites in Bosnia and Herzegovina (BiH). A combined regression and scaling approach was used for the reconstruction of the summer sunshine. We found a significant negative correlation $(r=-0.54, p<0.0001)$ with mean June-July sunshine hours from Osijek meteorological station (Croatia). The developed model was used for reconstruction of summer sunshine for the time period 1660-2010. We identified extreme summer events and compared them to available documentary historical sources of drought, volcanic eruptions and other reconstructions from the broader region. All extreme summers with low sunshine hours $(1712,1810,1815,1843,1899$ and 1966) are connected with volcanic eruptions.
\end{abstract}

\section{Introduction}

Documentary proxies of climate data from the 15th to the 19th centuries are well distributed over the Mediterranean region and are particularly abundant in Italy, France and the Iberian Peninsula, while they are less frequently found for the Balkan Peninsula area, i.e., Greece, former Yugoslavian countries, Albania, Bulgaria and Romania (Camuffo et al.,
2010). Dendrochronological studies of climate-tree growth relationships, such as the investigation of the southern part of Balkan Peninsula (Xoplaki et al., 2001), can help validate historical explanations of climate variability and its impact on human life. One of the first dendrochronological investigations on the Balkan Peninsula was a study covering the area of Greece, western Turkey, Cyprus and one location from Bosnia and Herzegovina $(\mathrm{BiH})$, by which an Aegean master tree-ring chronology was constructed (Kuniholm and Striker, 1983). With additional sampling of old houses and mosques, the chronology was extended back to $7000 \mathrm{BC}$ and one location each from Italy and $\mathrm{BiH}$ were added (Hughes et al., 2001). In the eastern part of the Balkan Peninsula, in south-western Bulgaria, 655-yr Bosnian pine (Pinus heldreichii Christ.) and 305-yr Macedonian pine (Pinus peuce Griseb.) chronologies were developed (Panayotov et al., 2010). Later, summer temperature was reconstructed (1768-2008), based on maximum latewood density measurements of $P$. heldreichii trees from a high-elevation stand in the Pirin Mountains in Bulgaria (Trouet et al., 2012). In Romania, the first 1000-yr Carpathian tree-ring width (TRW) stone pine (Pinus cembra L.) chronology has been established and summer mean temperatures reconstructed for the period 1163-2005 (Popa and Kern, 2009). In Albania, a 1391-yr TRW chronology (617-2008) was developed and maximum density measurements were acquired on living and dead P. heldreichii trees (Seim et al., 2010). A high positive correlation with summer, particularly August temperatures was found, but no significant correlation with precipitation. A similar study was performed on black pine (Pinus nigra Arnold) in Albania, whereby Levanič and Toromani (2010) developed a 238-yr TRW chronology. Tree-ring indices show 
a significantly negative response to summer temperatures and positive response to June precipitation. In sub-Mediterranean Slovenia, the formation of radial increments of $P$. nigra is stimulated by above-average winter and spring temperatures, while a negative impact of above-average temperatures in summer and during the entire vegetation period, from April through September, are clear (Ogrin, 2005). However, despite the numerous dendrochronological investigations across the Balkan Peninsula, climate reconstructions in the north-western part of Balkan Peninsula are still not available. Current dendrochronological investigations in developing TRW and maximum density chronologies from across the Balkan Peninsula - Slovenia (Hafner et al., 2011), Croatia, BiH (Poljanšek et al., 2012), and Montenegro (T. Levanič, personal communication, 2012), as well as Albania (Seim et al., 2012; Levanič and Toromani, 2010), Bulgaria (Trouet et al., 2012; Panayotov et al., 2010) and Romania (Levanič et al., 2012), should soon yield results that enhance our knowledge of past variation and contribute to dendroclimatological network of Balkan Peninsula (Luterbacher et al., 2012).

\subsection{Climate of the studied area}

Geographically, the Balkan Peninsula represents the border between Mediterranean and Central European climates. The combined impact determines the climate in the western part of the Balkan Peninsula as a mixture of continental climatic influence from the interior of the peninsula, mountain climatic influence from the Dinaric Alps and Mediterranean influence from the Adriatic Sea (Zupan Hajna, 2012). Annual precipitation and temperature regimes are characterised by seasonally diverse circulation patterns. In spring, an Atlantic High extending eastwards and over the Balkan Peninsula joins a low centre approaching from the southeast, causing a north-north-easterly flow over the eastern Mediterranean area. The extension of the summer Asian thermal low is evident throughout the eastern Mediterranean in all summer circulation patterns; however, it controls the weather in the region jointly with other principal pressure features (Kostopoulou and Jones, 2007). Multiproxy reconstructions of monthly and seasonal surface temperature fields for Europe back to 1500 show that the late 20th- and early 21stcentury European climate is very likely warmer than that of any time during the past $500 \mathrm{yr}$ (Luterbacher et al., 2004). In the light of projected climate change, heat waves in the Mediterranean region and on the Balkan Peninsula will intensify in the second half of the 21 st century - they will be more frequent and will last longer (IPCC, 2007). According to predictions, the minimum daily temperature during the "worst heat" events is expected to rise by around $3{ }^{\circ} \mathrm{C}$ (Meehl and Tebaldi, 2004). In the eastern Mediterranean and the Middle East, there will be a gradual and relatively strong warming of about $3.5-7^{\circ} \mathrm{C}$ between the $1961-1990$ reference period and the period 2070-2099 (Lelieveld et al., 2012). The observed daytime maximum temperatures appear to be increasing most rapidly in the northern part of the region, i.e., the Balkan Peninsula and Turkey. Hot summer conditions that rarely occurred in the reference period may become the norm by the middle or end of the 21 st century (Lelieveld et al., 2012). Moreover, a decrease in annual mean precipitation from $10 \%$ to more than $20 \%$ over some regions of the Mediterranean basin is expected by the end of the 21 st century (IPCC, 2001). In the eastern part of the Mediterranean basin, the observed strong drought period of the end of the twentieth century seems to be the strongest of the last $500 \mathrm{yr}$ (Nicault et al., 2008). It is therefore important to investigate whether extreme events have already occurred in $\mathrm{BiH}$ in the past and how trees responded to them. Results from our study can support study of climate, aridification processes (Kertész and Mika, 1999) and glaciation investigations (Hughes, 2010) from surrounding regions and $\mathrm{BiH}$.

\subsection{Species selection}

Selecting tree species growing on sites with limited betweentree competition and climate as the prevailing growthlimiting factor maximises the climate signal in tree-rings (Fritts, 1976). P. nigra was chosen for this study, since it grows on extreme sites, has a good response to climate (Lebourgeois, 2000) and reaches ages up to $500 \mathrm{yr}$ (Brus, 2004). The $P$. nigra area distribution covers the majority of the Mediterranean region (Vidaković, 1991), so the results of the climate-growth relationship from $\mathrm{BiH}$ can be compared to studies from other regions. Its growth response to climate has been studied in the western (Martín-Benito et al., 2010b, 2011) and eastern Mediterranean (Sevgi and Akkemik, 2007; Touchan et al., 2003), in the northern limit of its natural areal - in Austria (Leal et al., 2008) and south-eastern Romania (Levanič et al., 2012). Since the species is well-adapted to the Mediterranean and southern European climate, P. nigra tolerates summer droughts and high temperatures (Penuelas and Pilella, 2003), but poorly tolerates drought during early spring (Wimmer et al., 2000). Similar to trees in Spain (Martín-Benito et al., 2012) P. nigra growth on high elevated sites of Dinaric Mountains should be most strongly influenced by soil moisture. This environmental factor is in a tight connection with temperature, precipitation and cloud cover (Seneviratne et al., 2010). Variability in all these factors is explained with sunshine values, which also indirectly influences tree-growth (Fritts, 1976). Therefore, it should be possible to recover moisture stress-linked sunshine variance from tree-ring data (Stahle et al., 1991). As the different species respond to different climate parameters (GarcíaSuárez et al., 2009), it is important to test the presence of sunshine/moisture stress in TRW of $P$. nigra in $\mathrm{BiH}$.

In this paper we present results of climate/tree-growth analysis, based on a $P$. nigra TRW chronology from the north-western part of the Balkan Peninsula. The following aims were set: 
- Identification of the climate signal in the tree-ring widths of P. nigra in $\mathrm{BiH}$.

- Reconstruction of the most growth-limiting factor(s) for P. nigra.

- Identification of extreme climatic events in the past.

- Comparison of identified extreme events with published historical sources.

\section{Materials and methods}

\subsection{Site description and tree-ring data}

$\mathrm{BiH}$ is located between $42^{\circ} 26^{\prime}-45^{\circ} 15^{\prime}$ north and $15^{\circ} 44^{\prime}-$ $19^{\circ} 41^{\prime}$ east, in the north-western part of Balkan Peninsula. Seven sites, dispersed along the main mountain chain in $\mathrm{BiH}$, to cover the diverse climate of the studied region, were selected for this study (Fig. 1). The Krivaja and Konjuh sites are close to one another, but differ in altitude and aspect (Table 1). All sites are under the influence of a moist meridional maritime airflow from the Adriatic Sea, which often intrudes into the Balkan Peninsula where it collides with cooler air above the NW-SE oriented Dinaric mountain chain. This is the reason why there is a relatively high amount of precipitation over Dinaric mountains during growth season $(\mathrm{Zu}-$ pan Hajna, 2012). Average mean June-August temperature on high mountainous sites is $8.8^{\circ} \mathrm{C}$, while the amount of precipitation varies from $100 \mathrm{~mm}$ (Bjelašnica) to $280 \mathrm{~mm}$ (Čemerno station). Although there is more than $1000 \mathrm{~mm}$ (Bjelašnica) or $1600 \mathrm{~mm}$ (Čemerno) of annual of precipitation, the studied sites are in summer time generally dry because of mostly southern exposure, steep slopes and shallow soils.

Trees, used in this research, were sampled in the years 2005 and 2010. Individual TRW series were fitted with a cubic smoothing spline with a 50\% frequency response at $67 \%$ of the series length to remove non-climatic trends due to the tree's age, size, and the effects of stand dynamics (Cook and Briffa, 1990). Standardisation was done using ARSTAN for Windows, version 4.1d, the program provided by Cook and Krusic, Lamonth-Doherty Earth Observatory, Columbia University (http://www.ldeo.columbia.edu/ trl). The signal strength in the standardised chronology was tested using the Expressed Population Signal - EPS (Wigley et al., 1984). The calculation of EPS was based on a 50-yr running window, with a 25 -yr overlap. The usable portion of a chronology was defined as the part in which a minimum number of trees maintained an EPS value $\geq 0.85$ (Briffa and Jones, 1990). The data are archived at the Slovenia Forestry Institute and the full details of the sites and sampling strategies are included in Poljanšek et al. (2012).

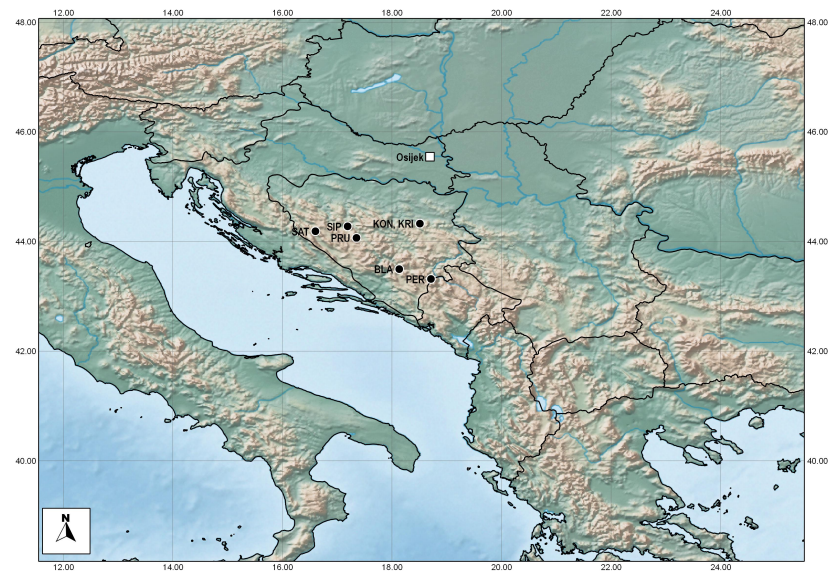

Fig. 1. Sampled sites, distributed along Dinaric mountains; Šator (SAT), Šipovo (SIP), Prusac (PRU), Blace (BLA), Peručica (PER), Konjuh (KON) and Krivaja (KRI), with meteorological station Osijek.

\subsection{Climate data}

Two different climate datasets, available for $\mathrm{BiH}$, were used in this research. The Histalp dataset contains temperature and precipitation data from various locations in $\mathrm{BiH}$, as well as sunshine data (1958-2007) for town Osijek in the continental part of Croatia (Auer et al., 2007). The second climate dataset consists of individual weather stations, provided by the Federal Hydrometeorological Institute of $\mathrm{BiH}$. These stations are Bjelašnica (2000 m a.s.1.), Čemerno (1305 m a.s.1.), SarajevoBjelave (630 ma.s.1.), Šipovo (460 ma.s.1.) and Tjentište (580 ma.s.1.). Some datasets have gaps in the annual base because climate data collection was disturbed twice due to a state of war. Bjelašnica mountainous weather station contains temperature data for time periods: 1895-1940, 19511992 and 2000-present, while precipitation data is available for time period 1952-2009. Sarajevo-Bjelave has a complete dataset from 1888 until the present. Other weather stations stopped collecting data due to disruption in 1992; Šipovo (1965-1992), Tjentište (1964-1992) and Čemerno (19581992).

\subsection{Statistical analysis}

Pearson's correlation coefficient $(r)$ was used to evaluate the relationship between annual radial growth of $P$. nigra and climate factors: precipitation, temperatures and sunshine. Simple mean of all standardised site chronologies was compared to monthly mean temperatures, monthly sum of precipitation and sunshine hours, to identify the most strongly correlated growth factor. In addition to simple monthly climate values, a number of seasonal climate data variables were generated and correlated with the tree-ring indices as well. After identification of the sunshine seasonal variable, we normalised the individual site chronologies using z-score values (Ljungqvist, 2010) and calculated their 
Table 1. General characteristics of sampled sites and number of trees sampled $(n)$ in Bosnia and Herzegovina.

\begin{tabular}{lllllllll}
\hline Site & Latitude/Longitude & Elevation & Slope & exposure & Bedrock & $n$ & Time span & EPS $\geq 0.85$ \\
\hline Blace & $43^{\circ} 31^{\prime} \mathrm{N} / 18^{\circ} 07^{\prime} \mathrm{E}$ & $950 \mathrm{~m}$ & $50^{\circ}$ & $\mathrm{SE}$ & dolomite & 21 & $1625-2010$ & 1830 \\
Konjuh & $44^{\circ} 17^{\prime} \mathrm{N} / 18^{\circ} 32^{\prime} \mathrm{E}$ & $1100 \mathrm{~m}$ & $45^{\circ}$ & $\mathrm{S}$ & serpentine & 24 & $1626-2010$ & 1705 \\
Krivaja & $44^{\circ} 13^{\prime} \mathrm{N} / 18^{\circ} 29^{\prime} \mathrm{E}$ & $500 \mathrm{~m}$ & $60^{\circ}$ & $\mathrm{NE}$ & serpentine & 18 & $1667-2010$ & 1745 \\
Peručica & $43^{\circ} 19^{\prime} \mathrm{N} / 18^{\circ} 42^{\prime} \mathrm{E}$ & $1450 \mathrm{~m}$ & $55^{\circ}$ & $\mathrm{S}$ & limestone & 33 & $1603-2010$ & 1660 \\
Prusac & $44^{\circ} 04^{\prime} \mathrm{N} / 17^{\circ} 21^{\prime} \mathrm{E}$ & $1100 \mathrm{~m}$ & $65^{\circ}$ & $\mathrm{S}$ & limestone & 15 & $1694-2010$ & 1825 \\
Šator & $44^{\circ} 11^{\prime} \mathrm{N} / 16^{\circ} 36^{\prime} \mathrm{E}$ & $1300 \mathrm{~m}$ & $55^{\circ}$ & $\mathrm{S}$ & dolomite & 20 & $1813-2010$ & 1870 \\
Šipovo & $44^{\circ} 17^{\prime} \mathrm{N} / 17^{\circ} 12^{\prime} \mathrm{E}$ & $1100 \mathrm{~m}$ & $60^{\circ}$ & $\mathrm{S} \& \mathrm{~N}$ & limestone & 35 & $1576-2005$ & 1730 \\
\hline
\end{tabular}

correlation coefficient with the most influential sunshine variable. Squared correlation coefficient $\left(r^{2}\right)$ shows the proportion of explained variance in each chronology and this value was used for the weighted mean regional chronology calculation (McCarroll et al., 2003). The significance of the summer sunshine signal strength between site chronologies in the two different time periods; the period of sunshine data (1958-2007) and the period pre-sunshine data (1813-1957) were tested using a z-test for the two correlation coefficients (Kanji, 1993). Linear model between regional chronology and sunshine season variable was calculated using linear regression. To assess the quality of the linear model for sunshine reconstruction, the period of the measured sunshine hours (1958-2007) was split into two equally long periods for calibration (1983-2007) and verification (1958-1982). The procedure was then repeated with the periods reversed. The reliability and prediction skill of the model was tested using reduction of error (RE) (Fritts, 1976), coefficient of efficiency (CE) (Cook et al., 1999) and the proportion of explained variability $\left(r^{2}\right)$. If RE and CE coefficients are higher than zero, the relationship has a predictive value, then a transfer function can be calculated and applied on the regional chronology. Applications of the transfer function on the chronology over a period of time for which there is no climate data results in reconstruction of the climate. We used this approach on the chronologies from 2010 to the year of 1660, when value of EPS drops below 0.85 threshold (Table 1). Finally, years of extreme summer sunshine values were defined as years with summer sunshine values of above or below a specified threshold. Positive and negative thresholds were calculated as one and two standard deviations (SD) from the mean value. The mean value of sunshine hours was calculated over the entire period of reconstruction (16602010). Positive values denote sunny summers, while negative values denote less-sunny summers. We used the term "lesssunny" to denote years with an unusually (below 1 or $2 \mathrm{SD}$ ) low number of mean June-July sunshine hours. Because the solar radiation can be reduced not only by the cloud cover (Suehrcke, 2000; Arking et al., 1996), but also by other factors, such as volcano eruptions (Handler, 1989), forest fires (Chubarova et al., 2008) and other aerosols (Satheesh and Krishna Moorthy, 2005; Moosmüller et al., 2009), we decided that the term less-sunny is the most appropriate.

\section{Results}

\subsection{Climate signal analysis}

Climate signal in the TRW of $P$. nigra was analysed using Pearson's correlation coefficient between climate data and mean standardised chronology; an average of seven site chronologies. The highest correlation coefficients for temperature and precipitation data were found using Bjelašnica weather station. There are positive correlations between spring temperature and summer precipitation and negative with summer temperature and tree growth. Above average number of sunshine hours in June and July has a significant negative effect on tree growth. Additionally, the correlation improves if months are combined into spring and summer periods (Fig. 2). According to the results of the correlation analysis, the strongest correlation among sunshine values was found with mean June-July sunshine hours $(r=-0.44$, $n=50, p<0.01)$. This climate proxy was tested for the long-term reconstruction. Between TRW and temperature, the strongest correlation was calculated with mean JuneAugust temperature $(r=-0.45, n=87, p<0.001)$, but this negative influence is more likely indirect, rather than direct, because temperature on mountainous sites cannot negatively influence tree-growth. The mean summer temperature at the Bjelašnica weather station site of $10^{\circ} \mathrm{C}$ does not exceed the optimal temperature for tree growth, set at $20^{\circ} \mathrm{C}$ for the moderate climate zone (Fritts, 1976). Negative influence of above average temperature on $P$. nigra growth is reasonable in area where summer temperature exceeds $20^{\circ} \mathrm{C}$, e.g. in Mediterranean area (Ogrin, 2005) but not at high elevations, where the majority of our sites are located. Precipitation signal is also significant ( $r=0.34, n=59, p<0.01$ ), but lower than temperature signal. Sunshine is not the growth limiting factor on this site, but its values are closely connected to moisture stress, which most logically drives the tree-growth (Alavi, 2002).

\subsection{Transfer function development}

We used z-test to test the differences in inter-correlations of seven site chronologies between the periods with and without sunshine data (1813-1957 and 1958-2007) - Table 2 . The period of pre-sunshine data is omitted with the 


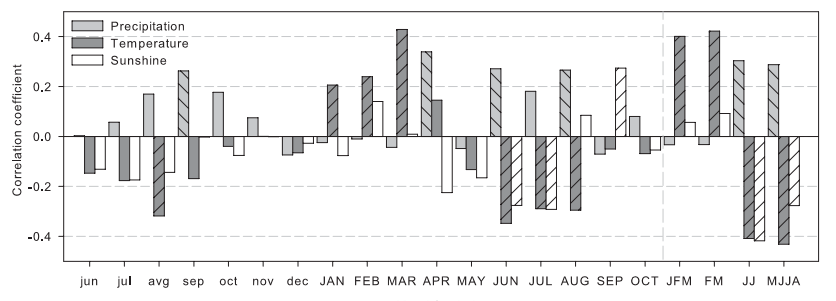

Fig. 2. Correlation coefficients (columns) between standardised chronology (average of seven site chronologies) and climate data from Bjelašnica weather station; precipitation with light grey, temperature with dark grey and sunshine hours with white columns (Osijek weather station). Columns with pattern represent significant value $(95 \%)$.

length of the shortest site chronology from Šator (18132010). The z-test confirmed that the results of correlation values among individual site chronologies in the period of sunshine data (1958-2007) and in the period of pre-sunshine data (1813-1957) do not differ. This confirms that the relative strength of the climate signal in the seven proxies remains constant through time. There are several ways in which the seven site chronologies can be combined to reconstruct the climate of the past (Trachsel et al., 2012; Briffa et al., 1988). We used weighted averaging, where the weight of each series is determined by the amount of variance in site chronologies, explained by sunshine. In this case all proxies that correlate strongly with sunshine data receive a high weight, irrespective of how highly they correlate with each other. This approach ensures that all strong proxies are included (McCarroll et al., 2013). The mean chronology, constructed using weighted averaging, correlates with mean June-July sunshine hours at $-0.54(n=50$, $p<0.0001$ ), more strongly than with simple averaging the site chronologies $(r=-0.44)$. The equation for the linear model between $\mathrm{BiH}$ regional chronology and sunshine hours from Osijek is $Y=271.424-11.592 \cdot X(n=50, F=12.9$, $p<0.001$ ), where $Y$ represents the mean June-July sunshine hours and $X$ are weighted TRW indices. Prediction skill and the stability of developed model were verified using a splitsample procedure (Table 3). The calibration-validation exercise indicated stability of the relationship over the two halves of the available instrumental data period. The similarity and strength of the derived calibration equations and verification tests of the two subset periods (Fig. 4) justify using the full period for developing the sunshine reconstruction. Additionally, the spatial strength of the weighted standardised chronology was tested using spatial correlation calculations in the KNMI Climate Explorer (van Oldenborgh, 1999). Our chronology correlates best with mean June-July Palmer Drought Severity Index (PDSI) for Europe, as a measure of soil moisture. Even though that solar radiation and sunshine hours vary significantly within the Carpathian-Balkan-Dinaric region (Niedźwiedź, 2012),
Table 2. Correlation values (Pearson's $r$ ) between the TRW series (individual site chronology and average, calculated as simple mean of all sites) over the calibration (upper triangle-period of measured sunshine data) and in the remainder of the common period (lower triangle-period before the measured sunshine data). No statistically significant differences were discovered between any of the pairs of correlation coefficients (z-test for two correlation coefficients).

\begin{tabular}{lcrrrrrrr}
\hline & \multicolumn{7}{c}{ Calibration period of measured sunshine data 1958-2007 } \\
\cline { 2 - 9 } Site & Blace & Konjuh & Krivaja & Peručica & Prusac & Šator & Šipovo & average \\
\hline Blace & & 0.33 & 0.30 & 0.42 & 0.39 & 0.06 & 0.36 & 0.61 \\
Konjuh & 0.45 & & 0.39 & 0.62 & 0.51 & 0.34 & 0.55 & 0.78 \\
Krivaja & 0.32 & 0.42 & & 0,36 & 0.39 & 0.33 & 0.44 & 0.66 \\
Peručica & 0.52 & 0.59 & 0.40 & & 0.65 & 0.37 & 0.62 & 0.78 \\
Prusac & 0.40 & 0.61 & 0.38 & 0.57 & & 0.42 & 0.70 & 0.79 \\
Šator & 0.08 & 0.30 & 0.22 & 0.25 & 0.33 & & 0.43 & 0.55 \\
Šipovo & 0.30 & 0.52 & 0.47 & 0.62 & 0.58 & 0.25 & & 0.79 \\
average & 0.66 & 0.80 & 0.66 & 0.79 & 0.78 & 0.48 & 0.74 & \\
\hline
\end{tabular}

Period before measured sunshine data 1813-1957.

we have calculated high correlation values in the region of Croatia $(0.6<r<0.5, p<0.05)$ and in the "triangle-like" area $(0.4<r<0.3, p<0.05)$ extending from Slovenia to Slovakia in the north and south to Greece (Fig. 3). This makes our regional chronology a valuable proxy for largescale summer sunshine hours reconstruction.

\subsection{Reconstruction and identification of extreme summers}

Mean value of June-July sunshine hours in the period of available data is $268 \mathrm{~h}$, with minimum value of 220 in the year of 1989 and maximum of 317 in 2000 . The total range of measured mean June-July sunshine values over the entire instrumental period $1958-2007$ is $96 \mathrm{~h}$, but the reconstructed range over the same period is only 43 ; a reduction of $55 \%$. To avoid this bias we "scaled" the proxy series so that it has the same mean and variance as the climatic target data over the calibration period (Esper et al., 2005; McCarroll et al., 2013). After scaling, reconstruction produces a range of $80 \mathrm{~h}$ over the instrumental period, a loss of only $17 \%$ comparing to the measured data. The threshold JuneJuly sunshine values of the period 1660-2010 were computed at $247 \mathrm{~h}(1 \mathrm{SD})$ and $226 \mathrm{~h}$ (2 SD) for identification of less-sunny summers and at $289 \mathrm{~h}(1 \mathrm{SD})$ and $310 \mathrm{~h}(2 \mathrm{SD})$ for very sunny summers. With sunny weather thresholds we were able to reconstruct 5 (2 SD) and 55 (1 SD) very sunny summers, while with less-sunny thresholds we identified 6 (2 SD) and 58 (1 SD) summers with less-sunny weather (Table 4). In the period of available sunshine data (1958-2007), we were successful at identifying the very sunny summer of 2000 and the less-sunny summers of 1966, 1974, 1975 and 1983, while we were just beneath 1 SD threshold level for extreme years (by just 4 sunshine hours per month) in years 1959, 1968, 1969, 1986 and 1988. Sampled trees failed to respond to low June-July sunshine values in 1989 and 2004, and high sunshine values in 2006 and 2007. 


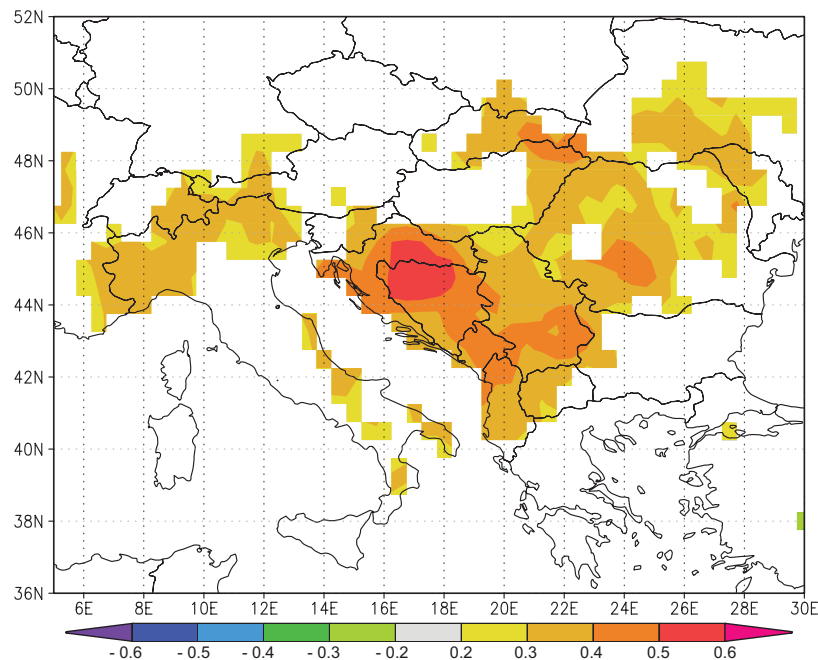

Fig. 3. Correlation values $(p<0.05)$ between weighted-TRW indices and mean June-July CRU Palmer Drought Severity Index (scPDSI), calculated in KNMI explorer (van Oldenborgh, 1999).

\section{Discussion}

\subsection{Climate signal and reconstruction}

Investigation of the climate signal in the $P$. nigra TRW chronologies is based on previously developed site chronologies for the north-western part of the Balkan Peninsula (Poljanšek et al., 2012). Each site chronology was compared to Bjelašnica climate data and sunshine data for Osijek area. Studies from the Alps report positive correlations with summer mean temperature (Rossi et al., 2007; Frank and Esper, 2005; Carrer et al., 2007), while sites from the Mediterranean area are more precipitation sensitive (Touchan et al., 2005). Variability of the radial growth of $P$. nigra from the mountainous western part of the Balkan Peninsula can be explained with the amount of summer sunshine hours, because June-July sunshine can be indirectly connected to moisture stress. So far, there are no results on cambium activity of $P$. nigra from $\mathrm{BiH}$, but we can assume that the June-July period is the most important part of the growing season for tree ring formation (Gričar and Čufar, 2008).

Although significantly positive, the precipitation signal in the TRW is not as strong as the sunshine signal. Natural $P$. nigra stands on mountainous sites are found on south facing slopes (Bussotti, 2002), where the trees with maximised climate signal can be expected. Soils on these sites have quite high infiltration rates in summer and much lower rates during the wet seasons (Cerdà, 1997). During spring trees access water, available in the shallow soil layers, while during summer drought, when the highest response to moisture stress would be expected, P. nigra trees conduct hydraulic lift and access deep water source (Penuelas and Pilella, 2003). They also have efficient drought-response of needle tracheids

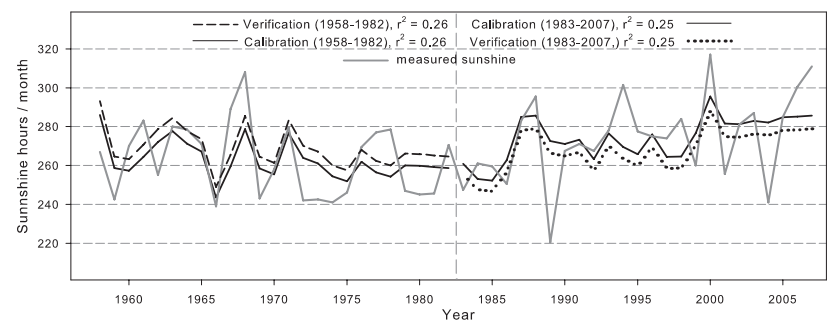

Fig. 4. Time series plots of measured (solid grey line) and reconstructed mean June-July sunshine hours for the calibration and verification periods of the split sample procedure (solid and dashed black line).

Table 3. Statistics of calibration/verification procedure between the $P$. nigra weighted mean chronology and mean June-July sunshine hours; RE - reduction of error; CE - coefficient of efficiency; $r^{2}$ squared regression coefficient or explained variance.

\begin{tabular}{lllll}
\hline & Calibration & \multicolumn{3}{c}{ Verification } \\
\cline { 3 - 5 } Period & $r^{2}$ & $r^{2}$ & RE & CE \\
\hline $1983-2007$ & $0.25^{\mathrm{a}}$ & $0.26^{\mathrm{b}}$ & 0.38 & 0.15 \\
$1958-1982$ & $0.26^{\mathrm{b}}$ & $0.25^{\mathrm{a}}$ & 0.34 & 0.17 \\
$1958-2007$ & $0.29^{\mathrm{c}}$ & & & \\
\hline Stars denote significance $\left({ }^{\mathrm{a}}=p<0.05, \mathrm{~b}=p<0.01,{ }^{\mathrm{c}}=p<0.001\right)$.
\end{tabular}

(Cochard et al., 2004) and possibly similar to P. sylvestris, water storage in the stem and branches (Waring et al., 1979). Furthermore, precipitation is locally distributed and therefore weather station data does not show the actual amount of precipitation at the sites. Annual precipitation along western part of Dinaric mountain chain reaches amounts of $2000 \mathrm{~mm}$ or more, for example, in year 1900, Bjelašnica station recorded $3157 \mathrm{~mm}$ of precipitation. One of the reasons for the high amount of precipitation is the Dinaric Mountains, which acts as a climatic barrier between Mediterranean and continental climate, similar to the Pirin Mountains in southwest Bulgaria which spatially mark a transition between the Mediterranean and temperate climate zones (Grunewald et al., 2009). All these factors contribute to relatively low correlation between mean monthly precipitation and tree-ring indices in $\mathrm{BiH}$, whereas an increasing influence of precipitation on treegrowth is observed towards the interior of the Balkan Peninsula in Romania (Levanič et al., 2012) and in the Central Europe in the Vienna basin region (Strumia et al., 1997), where $P$. nigra reacts more strongly to July rainfall. Similar results have also been reported from Turkey, where $P$. nigra responds positively to summer precipitation and not to temperature (Sevgi and Akkemik, 2007). In contrast to the relatively uniform response to a single climatic factor, a combined response of $P$. nigra to precipitation and temperature has been reported from Albania and Spain. In Albania, a significant negative response to June, July and August temperatures 
Table 4. List of years with extreme summers, aligned from the years with the highest standard deviation (SD) from the mean to years, closer to mean value. Event years in bold are common to results from other studies, see Table 5.

\begin{tabular}{llll}
\hline \multicolumn{2}{l}{ Sunny summers } \\
\hline 2 SD & $\mathbf{1 7 4 2}, \mathbf{1 9 0 8}, \mathbf{1 9 4 5}, \mathbf{1 6 9 5}, \mathbf{1 9 3 1}$ & \\
\hline \multirow{2}{*}{ S SD } & $\mathbf{1 7 2 5}, \mathbf{1 6 9 6}, 1929, \mathbf{1 9 5 0}, \mathbf{1 6 9 7}, 1947,1865,2000$, \\
& $\mathbf{1 8 0 2}, 1944, \mathbf{1 8 0 6}, \mathbf{1 7 8 2}, \mathbf{1 8 0 8}, \mathbf{1 6 9 4}, \mathbf{1 8 3 0}, 1958$, \\
& $1854, \mathbf{1 9 4 8}, 1909,1891, \mathbf{1 8 0 3}, 1773,1788,1932$, \\
& $\mathbf{1 7 0 7}, \mathbf{1 8 2 5}, 1933,1893,1779,1869,1702,1957$, \\
& $1698,1875,1840, \mathbf{1 8 0 7}, 1907,1703,1952,1741$, \\
& $1763,1666, \mathbf{1 7 8 4}, 1755, \mathbf{1 7 2 6}, \mathbf{1 7 8 9}, 1785,1863$, \\
& $1922,1868,1769, \mathbf{1 8 7 4}, \mathbf{1 9 4 6}, 1665, \mathbf{1 7 2 0}$ \\
\hline Less-sunny summers & \\
\hline 2 SD & $\mathbf{1 8 9 9}, \mathbf{1 8 4 3}, \mathbf{1 8 1 0}, \mathbf{1 8 1 5}, \mathbf{1 7 1 2}, 1966$ \\
\hline 1 SD & $1818,1816,1814,1799,1736, \mathbf{1 7 7 2}, 1985,1838$, \\
& $1984,1885,1926, \mathbf{1 8 4 5}, \mathbf{1 8 7 1}, 1821, \mathbf{1 9 1 4}, 1681$, \\
& $1682,1683, \mathbf{1 6 9 2}, 1819, \mathbf{1 7 1 4}, \mathbf{1 8 3 3}, 1879, \mathbf{1 9 7 5}$, \\
& $\mathbf{1 6 9 1}, 1680, \mathbf{1 9 1 3}, \mathbf{1 8 7 6}, 1837, \mathbf{1 6 9 3}, 1897, \mathbf{1 9 1 5}$, \\
& $1900,1713, \mathbf{1 8 3 2}, \mathbf{1 8 4 6}, \mathbf{1 8 4 4}, 1898,1820,1886$, \\
& $1974,1978,1684,1722, \mathbf{1 7 8 3}, 1902,1679,1813$, \\
& $1826,1738, \mathbf{1 9 7 0}, 1983,2009, \mathbf{1 7 2 9}, \mathbf{1 9 1 2}, \mathbf{1 9 2 7}$, \\
& 1780,1936
\end{tabular}

and positive response to June precipitation on the tree radial growth has been observed (Levanič and Toromani, 2010). In Spain, the standardised precipitation-evapotranspiration index is recognised as the main climatic driver of P. nigra radial growth (Martín-Benito et al., 2012), although the trees are still sensitive to July and August temperature and precipitation (Martín-Benito et al., 2010a). Beside significant correlations between summer climate factors and TRW indices in $\mathrm{BiH}$, we also discovered a positive correlation $(r=0.35$, $p<0.01$ ) with spring temperatures as well (Fig. 2). Spring (January to March) temperatures have no direct influence on cambium activity, but their positive influence on radial growth can be explained through early start of cambium activity in warm March and with water availability at the beginning of the growing period. Mild and wet winters over the western part of the Balkan Peninsula are connected to negative North Atlantic Oscillation (NAO) phases (LópezMoreno et al., 2011; Vicente-Serrano and López-Moreno, 2005). In negative NAO winters, the western Balkans experience anomalously cyclonic circulation and enhanced precipitation and therefore sufficient soil recharge which has a positive influence on a wider radial increment of $P$. nigra.

When testing the ability of the linear model to reconstruct June-July sunshine hours, decreased sensitivity of radial growth to summer sunshine between 1977 and 1985 was noticed (Fig. 4). In this period trees have complacent rings, giving an impression of very little climatic influence on annual tree growth. According to Mariotti and Dell'Aquila (2012), this period from the end of the 1960s to the beginning of the 1990s was characterised by outstanding decadal variations of summer sunshine values and therefore temperatures over the entire Mediterranean region, with maximum of the precipitation trends in the 1960s (Xoplaki et al., 2006). The summer of 1976 was the coolest summer of the second half of the twentieth century over the northeastern Mediterranean, while this same summer was one of the hottest and driest in the United Kingdom (Xoplaki et al., 2003a). Mediterranean summer temperature anomalies were also very well reflected in $\mathrm{BiH}$, where the coolest summer was recorded in 1974 and the warmest summers in 1994, 1998 and 2000. The trend for the period 1950 to 1960 is $-1.15^{\circ} \mathrm{C}$ per decade, whereas a trend of $0.5^{\circ} \mathrm{C}$ per decade was recorded for the period between 1980 and 1999 (Xoplaki et al., 2003b). There is also a clear tendency for wetter summers between 1967 and 1985 over the Balkan region, when compared to previous decades (Blade et al., 2011). In our research we identified summer 2000 as sunny and 1974 as less-sunny (Table 4). Also, from the period of wetter summers 1967-1985, we identified 7 out of 19 summers as less-sunny (1970, 1974, 1975, 1978 and 1983-1985). Regional processes and feedbacks modulate the influence of large scale anomalies during summer over the Mediterranean. Mariotti and Dell'Aquilla (2012) have shown that these processes may involve cloud cover, land surface modifications and include positive soil moistureprecipitation and soil moisture-temperature feedback. Many regional processes that were modified due to increased summer NAO could mask the significant relationships among precipitation, temperature and tree growth. These processes can have a profound impact on tree growth, since incoming solar radiation and moderate heat flux are supporting factors for growth (Weitzenkamp et al., 2007). Changes in incoming solar radiation due to increased cloud cover could weaken the temperature and precipitation growth relationships of $P$. nigra by having a direct effect on gross primary production. Identification of significant processes is beyond the scope of this article but should be addressed in future studies.

\subsection{Identification of extreme summer events}

In our reconstruction there is a noticeable period from the beginning of the reconstruction in 1660 until 1695 (Fig. 5). This period is part of the Late Maunder Minimum (Luterbacher et al., 2001) and it signifies the climax of the so-called "Little Ice Age" in which Europe experienced predominant cooling (Xoplaki et al., 2001) and marked climate variability (Luterbacher et al., 2000). Summers in western and central Europe were wetter and slightly cooler than they are today due to a weaker Azores high (Luterbacher et al., 2001). During "Little Ice Age", the period 1725-1775 was warm and sunny in northern Norway (Young et al., 2010), while in $\mathrm{BiH}$ we noticed sunny period from 1695-1790 (Fig. 5). The coldest decade of the millennium over the Northern Hemisphere was in 1691-1700 (Jones et al., 1998). This partly 
Table 5. Records of reconstructed sunny/less-sunny summers based on TRW from BiH, with standard deviations (SD) and their comparison with other related available documentary sources.

\begin{tabular}{|c|c|c|c|c|}
\hline Sunny & Less-sunny & SD & Historical event & Reference \\
\hline & 1975 & 1 & Slovakia: wet in June-August & Büntgen et al. (2010b) \\
\hline & 1970 & 1 & Slovakia: wet in June-August & Büntgen et al. (2010b) \\
\hline 1950 & & 1 & Italy, south area: one of the hottest summers & Camuffo et al. (2010) \\
\hline 1948 & & 1 & Slovakia: dry spell from March-August & Büntgen et al. (2010b) \\
\hline 1946 & & 1 & SW Romania: year of great famine & Levanič et al. (2012) \\
\hline 1945 & & 2 & $\begin{array}{l}\text { Driest years in Bulgaria during the 20th } \\
\text { century (1945 and 2000) }\end{array}$ & Koleva and Alexandrov (2008) \\
\hline \multirow[t]{3}{*}{1931} & & 2 & Warm period in Bulgaria & Trouet et al. (2012) \\
\hline & 1927 & 1 & Slovakia: wet from March-August & Büntgen et al. (2010b) \\
\hline & $1912-1915$ & 1 & Taal eruption, Indonesia in 1911 & Mastin and Witter (2000) \\
\hline \multirow[t]{3}{*}{1908} & & 2 & Anatolia: major drought and famine event & Akkemik et al. (2005) \\
\hline & 1899 & 2 & Etna eruption: central explosion in July & Bonaccorso et al. (2004) \\
\hline & 1876 & 1 & Czech Lands: downpours in summer with local floods & Büntgen et al. (2010b) \\
\hline \multirow[t]{5}{*}{1874} & & 1 & Province of Ankara, Turkey: a devastating drought & Touchan et al. (2007) \\
\hline & 1871 & 1 & Czech Lands: 3 weeks of rain in July-August & Büntgen et al. (2010b) \\
\hline & $1844-1846$ & 1 & Etna eruption in 1842 and 1843 , clouds in $1844-1846$ & Bonaccorso et al. (2004) \\
\hline & 1843 & 2 & Etna eruption in 1842 and 1843 , clouds in $1844-1846$ & Bonaccorso et al. (2004) \\
\hline & $1832-1833$ & 1 & Etna eruptions in 1831 caused clouds in $1832-1833$ & Bonaccorso et al. (2004) \\
\hline 1830 & & 1 & Slovenia: great heat and drought in July and August & Ogrin $(2002)$ \\
\hline \multirow[t]{3}{*}{1825} & & 1 & $\begin{array}{l}\text { Slovakia: dry and warm April; long-lasting drought before } \\
\text { late July; Czech Lands: very dry in July }\end{array}$ & Büntgen et al. (2010b) \\
\hline & 1815 & 2 & Volcano Tambora explosion, Indonesia in April & Xoplaki et al. (2001), Boers (1995) \\
\hline & 1810 & 2 & Large stratospheric eruption in 1809 of a volcano in the tropics & Cole-Dai et al. (2009) \\
\hline $1806-1808$ & & 1 & Slovakia: dry and warm in May-August & Büntgen et al. (2010b) \\
\hline $1802-1803$ & & 1 & Serbia: the lack of rain from May until October & Xoplaki et al. (2001) \\
\hline 1789 & & 1 & Slovakia: great drought in May-June & Büntgen et al. (2010b) \\
\hline \multirow[t]{2}{*}{1782,1784} & & 1 & Romania: extremely dry years & Levanič et al. (2012) \\
\hline & 1783 & 1 & Eruption of Laki in southern Iceland & Grattan and Pyatt (1999) \\
\hline \multirow[t]{2}{*}{1782} & & 1 & Slovakia: hot two weeks in June, warmth continuing in July-August & Büntgen et al. (2010b) \\
\hline & 1772 & 1 & Czech Lands: rainy June & Büntgen et al. (2010b) \\
\hline \multirow[t]{2}{*}{1742} & & 2 & Anatolia: extremely dry year & Akkemik et al. (2005) \\
\hline & 1729 & 1 & SE Romania: extremely wet year & Levanič et al. (2012) \\
\hline \multirow[t]{2}{*}{1725,1726} & & 1 & SE Romania: drought in 1725 & Levanič et al. (2012) \\
\hline & & & Anatolia: 2-yr long major drought & Touchan et al. (2007) \\
\hline \multirow[t]{3}{*}{1720} & & 1 & Mediterranean: one of the hottest summers & Camuffo et al. (2010) \\
\hline & 1712 & 2 & Greece: drought, bad harvest, high prices, famine & Xoplaki et al. (2001) \\
\hline & $1712-1714$ & 2 & Awu eruption on December, 1711 in Indonesia & Clor et al. (2005) \\
\hline 1707 & & 1 & Anatolia: dry year & Akkemik et al. (2005) \\
\hline 1696,1697 & & 1 & Anatolia: dry years & Akkemik et al. (2005) \\
\hline \multirow[t]{4}{*}{1695} & & 2 & Cold summer, famine in England, Ireland & Lindgrén and Neumann (1981) \\
\hline & $1691-1694$ & 1 & Crete: bad harvest, famine, high prices olive-oil & Xoplaki et al. (2001) \\
\hline & $1691-1693$ & 1 & Northern Hemisphere: & Jones et al. (1998) \\
\hline & & & The coldest decade $1691-1700$ of the millennium & \\
\hline
\end{tabular}

fits to our results, as the years of 1679-1684 and 1691-1693 were recognised as years with less-sunny summers. But afterwards, our reconstruction shows the period of 1694-1698 as years with sunny summers and even more; the summer of 1695 was recognised as the fourth sunniest summer in our reconstruction (Table 4). In the northern and continental part of Europe, this year was extremely cold and wet (Lindgrén and Neumann, 1981), while in Aegean sea area drought in the autumn destroyed harvest (Xoplaki et al., 2001). This long dry period from the late autumn of November 1695 to January-February of 1696 resulted from anticyclone conditions prevailing over central, eastern and south-eastern Europe, which prevented crossing of low-pressure systems towards the Balkans (Xoplaki et al., 2001). This, dominant atmospheric circulation pattern between the British Isles and Balkan Peninsula, has been also recorded by a summer reconstruction from north-eastern Mediterranean (Trouet et al., 2012). On a smaller scale, our results support this strong and consistent anti-phase relationship, which suggests that the summer NAO pattern is the main driving force of the teleconnection between summer temperatures in south-eastern versus north-western Europe (Trouet et al., 2012). We support this idea with identification of extremes (Table 4). In general, summers with low values of sunshine hours are related to oscillation patterns from continental Europe and regions north of $\mathrm{BiH}$; e.g. 1975, 1970, 1927, 1876, 1871 and 


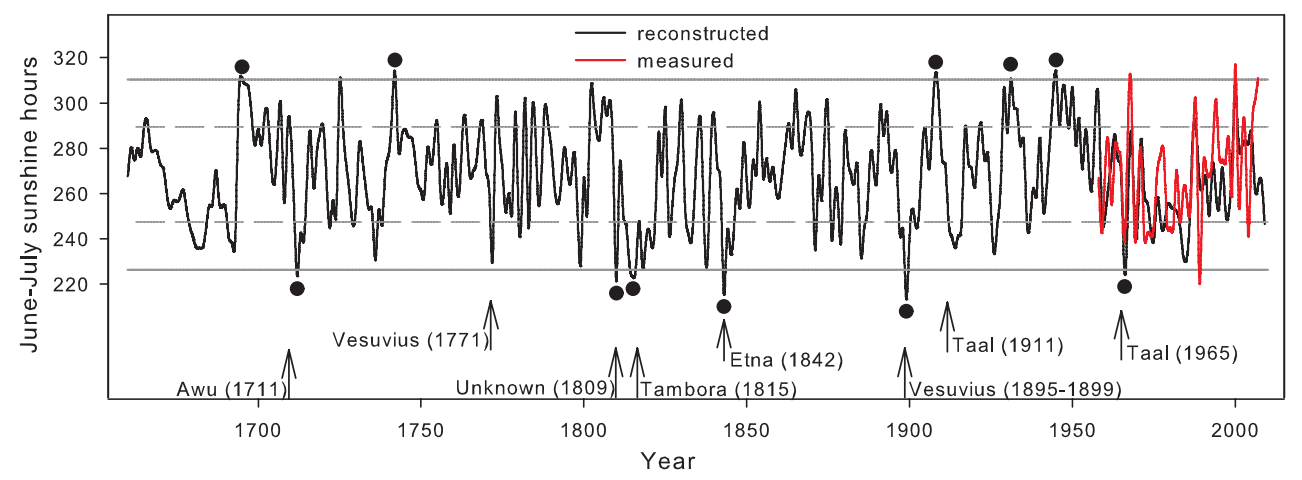

Fig. 5. Reconstructed (black line) and measured (shorter red line) mean June-July sunshine hours. Solid grey lines delineate two, while dashed grey lines represent one standard deviation from the mean, calculated over the reconstructed period 1660-2010. Black dots mark identified extreme summers and arrows indicate larger volcano eruptions; Awu (Clor et al., 2005), Vesuvius (Scandone et al., 2008), unknown and Tambora (Cole-Dai et al., 2009), Etna (Bonaccorso et al., 2004) and Taal (Mastin and Witter, 2000).

1772. On the other hand, sunny summers are more related to oscillations from the south-eastern and continental part of Balkan Peninsula; e.g. 1945, 1931, 1802, 1784 and 1729, or south-eastern/eastern Mediterranean; e.g. 1950, 1908, 1874, 1742, 1725, 1726, 1720, 1707 etc. (Table 5). The BiH area proved to be a good area for further extreme climatic events investigations, as it is located in the transition zone between Mediterranean and continental influence, therefore the trees react to climatic extremes from both zones. This could be the reason why we have many common summer climatic events with Slovakia, and on the other hand years when growth seasons were different between these two regions. For example, cold and wet conditions in the spring of 1725 prevailed over Slovakia and later during the summer, extensive anomalous low-pressure conditions, extending from northern to central Europe, have been connected with disastrous floods in Slovakia (Brázdil et al., 2008), while BiH and Romania (Levanič et al., 2012) were influenced by the hot, sunny summer weather from the eastern Mediterranean, similar to Anatolia and Syria (Touchan et al., 2007). After severe and snowy winter 1725/1726 in Slovakia (Brázdil et al., 2008), summer drought extended from Turkey (Touchan et al., 2007) and influenced both; BiH and Slovakia area (Brázdil et al., 2008).

Special awareness must be made when identifying extreme years and their possible causes. With mean June-July sunshine hours, we explain $21 \%$ of the variability of the TRW indices. Aside to negative summer sunshine correlation values, there is also a positive correlation between TRW indices and spring temperatures (Fig. 2). This means that extremely cold winters could affect the cambium and limit its activity (Jyske et al., 2012). In such years TRW could be narrower, despite the possible good growth conditions later in the summer. Therefore, it is important to verify newly identified extreme climatic events (Table 5). One such case is the winter 1782. This winter is reported to be harsh and cold in Greece, with Lake Karla freezing and the destruction of olive and fruit trees, death of animals; for $\mathrm{BiH}$ plague and the deaths of people are mentioned (Xoplaki et al., 2001). Later in that year, drought events during the summer season extended north to Slovakia (Büntgen et al., 2010a), east to Romania (Levanič et al., 2012) and to the western Black Sea region of Turkey (Akkemik et al., 2005). The summer of 1782 was also recognised in our reconstruction as a year with high moisture stress during the growing season. The next example happened in the period of existing instrumental data in BiH. Winter of 1928/1929 was characterised as extremely cold in Slovakia (Büntgen et al., 2011) and as the winter when sea froze in the Venice lagoon (Winchester, 1930). The measured mean January-March temperature in 1929 for Sarajevo-Bjelave was, according to Federal Hydrometeorological Institute of $\mathrm{BiH},-20^{\circ} \mathrm{C}$, while the long-term average (1889-2009) is $-11^{\circ} \mathrm{C}$. In the following summer season mean temperature did not differ from long-term mean, but our reconstruction showed summer with above average sunshine hours (Table 4).

In search for explanations for less-sunny summer events, we also reviewed the influence of natural forcing on climate of the western part of Balkan Peninsula. The years with surprisingly low summer sunshine values matched well with years of major volcanic eruption, similar to strong volcanic forcing system in the North (McCarroll et al., 2013). This impact can be seen in abrupt change in the same growth year, lagged by one year, or as a prolonged effect, due to the influence of volcanic eruptions and sulphate loadings and consequently on tree-growth (Breitenmoser et al., 2012). We noticed the importance of strength, location and the length of volcano eruption, as well as the season of activity (Mastin and Witter, 2000). In the years of 1666, 1695 and 1698 Kuwae volcano erupted in the southwest Pacific (Briffa et al., 1998). While years 1666 and 1695 are both the dates of the eruption, our study identifies them as sunny. This indicates that western part of Balkan Peninsula was not influenced by volcanic eruptions from south-western Pacific. On the other hand, Tambora explosion in Indonesia (1815), 
whose eruption is counted as the largest historically documented eruption of the modern (instrumental) era (Briffa et al., 1998), is recorded in our tree ring series as the fourth summer with the lowest sunshine values in the reconstruction period. After Tambora, eruptions of Raung and Ijen, also from Indonesia, took place in the year 1817 (Mastin and Witter, 2000). Our reconstruction describes the period of 1813 1821 , with exception of 1817 , as summers with a low number of sunshine hours. This decade is also counted as probably the coolest in the last $500 \mathrm{yr}$ (Cole-Dai et al., 2009). We can consider that one massive eruption has influence on more growth periods, like Taal volcanic eruption from Philippines in the 1911 (Mastin and Witter, 2000), which seems to have affected tree growth in $\mathrm{BiH}$ in the following $4 \mathrm{yr}$ (19121915). We observed the same results in the years after Krakatoa eruption in 1883 (Rampino and Self, 1982). Closer to BiH an eruption of volcano Vesuvius (Italy) happened in May, 1771 and lasted for a whole month (Scandone et al., 2008). Its influence is not recorded in the same year, but the following summer had low value of sunshine hours (Table 4). Influence of longer volcanic eruptions on tree-growth is seen in the long Vesuvius eruption, starting in July, 1895 and lasting till September, 1899, being active for more than 1500 days (Scandone et al., 2008). Vesuvius is located southwest from $\mathrm{BiH}$, but as there is in the beginning of the growing season a north-northeasterly flow over the eastern Mediterranean area (Kostopoulou and Jones, 2007), volcanic dust was transported towards the Dinaric mountains. This explains why we identified following years 1897-1900 and 1902 as less-sunny (1 SD) and 1899 as year with extremely low amount of sunshine (Table 4). With volcanic eruptions, we connected all summers with sunshine values below 2 SD; Vesuvius in 1899 (Scandone et al., 2008), Etna (Italy) in 1843 (Bonaccorso et al., 2004), unknown in 1810 and Tambora in 1815 (Cole-Dai et al., 2009), Awu (Indonesia) in 1712 (Clor et al., 2005) and Taal in 1966 (Mastin and Witter, 2000). The results of this research open many new fields of potential future investigations. But for a more detailed examination of the discovered $\mathrm{BiH}$ extreme summer sunshine events and their connection to volcanic eruptions, further inquiries with applications of data on sulphur loadings, power of eruption and its length should be addressed. Further, special investigation on available documentary archives with an emphasis on the whole region of the western Balkans is needed. Especially for those events which may be limited to the $\mathrm{BiH}$ area only and are not confirmed by documentary sources from outside the $\mathrm{BiH}$.

\section{Conclusions}

We conclude that summer mean June-July sunshine hours from Osijek station (Croatia) are the most appropriate proxy for the moisture stress, which influences the radial growth of P. nigra in mountainous sites in the Bosnia and Herzegovina area. With application of the z-score method and weighted mean calculation, one reliable regional chronology, as a representative for the whole western part of Balkan Peninsula, was calculated. With values of 2 SD for identifying extreme climatic events, we discovered 5 extremely sunny $(1742,1908,1945,1695,1931)$ and 6 summers with extremely low values of sunshine hours $(1899,1843,1810$, 1815,1712 , 1966). All identified 6 summers with the lowest number of sunshine hours from $\mathrm{BiH}$ area are connected to volcanic eruptions in the past. Major part of other lesssunny summer events overlap with reported events from regions north of the Balkan Peninsula, while sunny summer events are more related to events from inner, continental part of Balkan Peninsula or Mediterranean area. Besides climate forcing of moisture stress, impact of volcanic eruptions have been connected and their influence discussed, but for detailed explanation of the relation between moisture stress and sunshine values, more thorough identification of these relationships, including multispecies tree ring network and/or isotope analysis, should be addressed in the future.

Acknowledgements. We would like to express our special thanks to Dalibor Ballian from the Faculty of Forestry, Sarajevo for providing us with strong field support and for making this study possible. We are also grateful to forestry personnel from Bosansko Grahovo, Konjuh, Konjic, Prusac, Šipovo, rangers from Peručica National Park, and to the Federal Hydrometeorological Institute of Bosnia and Herzegovina for supplying us with the meteorological data used in this study. We thank Maarten de Groot for advice on statistical analysis of the data. We also thank Špela Jagodic and Robert Krajnc for their valuable assistance in the field and laboratory. A warm thanks to reviewers for their constructive suggestions that helped us improve the paper. This work was supported by the Slovenian Research Agency through the program and research group "Forest, biology, ecology and technology" P4-0107, a doctoral study grant from Simon Poljanšek and EUFORINNO project (European Forest Research and Innovation, Grant Agreement No. 315982); EU 7th Frame Work Programme - REGPOT 6/2012-12/2015.

Edited by: J. Luterbacher

\section{References}

Akkemik, Ü., Dağdeviren, N., and Aras, A.: A preliminary reconstruction (A.D. 1635-2000) of spring precipitation using oak tree rings in the western Black Sea region of Turkey, Int. J. Biometeorol., 49, 297-302, doi:10.1007/s00484-004-0249-8, 2005.

Alavi, G.: The impact of soil moisture on stem growth of spruce forest during a 22-year period, Forest Ecol. Manag., 166, 17-33, doi:10.1016/s0378-1127(01)00661-2, 2002.

Arking, A., Chou, M., Dah, M., and Ridgway, W. L.: On estimating the effect of clouds on atmospheric absorption based on flux observations above and below cloud level, Geophys. Res. Lett., 23, 829-832, doi:10.1029/96g100775, 1996.

Auer, I., Böhm, R., Jurkovic, A., Lipa, W., Orlik, A., Potzmann, R., Schöner, W., Ungersböck, M., Matulla, C., Briffa, K., Jones, P., Efthymiadis, D., Brunetti, M., Nanni, T., Maugeri, M., Mer- 
calli, L., Mestre, O., Moisselin, J.-M., Begert, M., MüllerWestermeier, G., Kveton, V., Bochnicek, O., Stastny, P., Lapin, M., Szalai, S., Szentimrey, T., Cegnar, T., Dolinar, M., GajicCapka, M., Zaninovic, K., Majstorovic, Z., and Nieplova, E.: HISTALP - historical instrumental climatological surface time series of the Greater Alpine Region, Int. J. Climatol., 27, 17-46, doi:10.1002/joc.1377, 2007.

Blade, I., Liebmann, B., Fortuny, D., and Van Oldenborgh, G. J.: Observed and simulated impacts of summer NAO in Europe: implications for projected drying in the Mediterranean region, Clim. Dynam., 39, 709-727, doi:10.1007/s00382-011-1195-x, 2011.

Boers, B. D. J.: Mount Tambora in 1815: A Volcanic Eruption in Indonesia and Its Aftermath, Indonesia, 60, 37-60, doi:10.2307/3351140, 1995.

Bonaccorso, A., Calvari, S., Coltelli, M., Negro, C. D., and Falsaperla, S.: Mt. Etna: volcano laboratory, American geophysical union, Washington DC, 2004.

Brázdil, R., Kiss, A., Luterbacher, J., and Valášek, H.: Weather patterns in eastern Slovakia 1717-1730, based on records from the Breslau meteorological network, Int. J. Climatol., 28, 16391651, doi:10.1002/joc.1667, 2008.

Breitenmoser, P., Beer, J., Brönnimann, S., Frank, D., Steinhilber, F., and Wanner, H.: Solar and volcanic fingerprints in tree-ring chronologies over the past 2000 years, Palaeogeogr. Palaeocl., 313-314, 127-139, doi:10.1016/j.palaeo.2011.10.014, 2012.

Briffa, K. R. and Jones, P. D.: Basic chronology statistics and assessment, in: Methods of dendrochronology: applications in the environmental sciences, edited by: Cook, E. R. and Kairiukstis, L. A., Kluwer academic publishers, Dordrecht, Boston, London, 137-152, 1990.

Briffa, K. R., Jones, P. D., and Schweingruber, F. H.: Summer temperature patterns over Europe: A reconstruction from 1750 A.D. based on maximum latewood density indices of conifers, Quaternary Res., 30, 36-52, doi:10.1016/0033-5894(88)90086-5, 1988.

Briffa, K. R., Jones, P. D., Schweingruber, F. H., and Osborn, T. J.: Influence of volcanic eruptions on Northern Hemisphere summer temperature over the past 600 years, Nature, 393, 450-455, 1998.

Brus, R.: Drevesne vrste na slovenskem (Tree species on slovenian area; in Slovenian), Mladinska založba, Ljubljana, 2004.

Büntgen, U., Brázdil, R., Dobrovolný, P., Trnka, M., and Kyncl, T.: Five centuries of Southern Moravian drought variations revealed from living and historic tree rings, Theor. Appl. Climatol., 105, 1-14, doi:10.1007/s00704-010-0381-9, 2010a.

Büntgen, U., Brázdil, R., Frank, D., and Esper, J.: Three centuries of Slovakian drought dynamics, Clim. Dynam., 35, 315-329, doi:10.1007/s00382-009-0563-2, 2010b.

Büntgen, U., Brázdil, R., Heussner, K.-U., Hofmann, J., Kontic, R., Kyncl, T., Pfister, C., Chromá, K., and Tegel, W.: Combined dendro-documentary evidence of Central European hydroclimatic springtime extremes over the last millennium, Quaternary Sci. Rev., 30, 3947-3959, doi:10.1016/j.quascirev.2011.10.010, 2011.

Bussotti, F.: Pinus nigra, in: Pines of silvicultural importance, C.A.B. International, CABI Publishing, 266-286, 2002.

Camuffo, D., Bertolin, C., Barriendos, M., Dominguez-Castro, F., Cocheo, C., Enzi, S., Sghedoni, M., della Valle, A., Garnier, E., Alcoforado, M. J., Xoplaki, E., Luterbacher, J., Diodato, N., Maugeri, M., Nunes, M. F., and Rodriguez, R.: 500-year temper- ature reconstruction in the Mediterranean Basin by means of documentary data and instrumental observations, Climatic Change, 101, 169-199, doi:10.1007/s10584-010-9815-8, 2010.

Carrer, M., Nola, P., Eduard, J. L., Motta, R., and Urbinati, C.: Regional variability of climate-growth relationships in Pinus cembra high elevation forests in the Alps, J. Ecol., 95, 1072-1083, doi:10.1111/j.1365-2745.2007.01281.x, 2007.

Cerdà, A.: Seasonal changes of the infiltration rates in a Mediterranean scrubland on limestone, J. Hydrol., 198, 209-225, doi:10.1016/s0022-1694(96)03295-7, 1997.

Chubarova, N. Y., Prilepsky, N. G., Rublev, A. N., and Riebau, A. R.: Chapter 11 A Mega-Fire Event in Central Russia: Fire Weather, Radiative, and Optical Properties of the Atmosphere, and Consequences for Subboreal Forest Plants, in: Developments in Environmental Science, edited by: Bytnerowicz, A., Arbaugh, M. J., Riebau, A. R., and Christian, A., Elsevier, 247-264, 2008.

Clor, L. E., Fischer, T. P., Hilton, D. R., Sharp, Z. D., and Hartono, U.: Volatile and $\mathrm{N}$ isotope chemistry of the Molucca Sea collision zone: Tracing source components along the Sangihe Arc, Indonesia, Geochem. Geophy. Geosy., 6, Q03J14, doi:10.1029/2004gc000825, 2005.

Cochard, H., Froux, F., Mayr, S., and Coutand, C.: Xylem Wall Collapse in Water-Stressed Pine Needles, Plant Physiol., 134, 401408, doi:10.1104/pp.103.028357, 2004.

Cole-Dai, J., Ferris, D., Lanciki, A., Savarino, J., Baroni, M., and Thiemens, M. H.: Cold decade (AD 1810-1819) caused by Tambora (1815) and another (1809) stratospheric volcanic eruption, Geophys. Res. Lett., 36, L22703, doi:10.1029/2009g1040882, 2009.

Cook, E. R. and Briffa, K. R.: A comparison of some tree-ring standardization methods, in: Methods of Dendrochronology: Applications in the Environmental Sciences, edited by: Cook, E. R and Kairiukstis, L. A., Kluwer Academic Publishers, Dordrecht, Boston, London, 153-162, 1990.

Cook, E. R., Meko, D. M., Stahle, D. W., and Cleaveland, M. K.: Drought Reconstructions for the Continental United States, J. Climate, 12, 1145-1162, doi:10.1175/15200442(1999)012<1145:drftcu>2.0.co;2, 1999.

Esper, J., Frank, D. C., Wilson, R. J. S., and Briffa, K. R.: Effect of scaling and regression on reconstructed temperature amplitude for the past millennium, Geophys. Res. Lett., 32, L07711, doi:10.1029/2004g1021236, 2005.

Frank, D. and Esper, J.: Characterization and climate response patterns of a high-elevation, multi-species tree-ring network in the European Alps, Dendrochronologia, 22, 107-121, 2005.

Fritts, H. C.: Tree rings and climate, Academic Press, London, New York, San Francisco, 567 pp., 1976.

García-Suárez, A. M., Butler, C. J., and Baillie, M. G. L.: Climate signal in tree-ring chronologies in a temperate climate: A multi-species approach, Dendrochronologia, 27, 183-198, doi:10.1016/j.dendro.2009.05.003, 2009.

Grattan, J. P. and Pyatt, F. B.: Volcanic eruptions dry fogs and the European palaeoenvironmental record: localised phenomena or hemispheric impacts?, Global Planet. Change, 21, 173-179, doi:10.1016/s0921-8181(99)00013-2, 1999.

Gričar, J. and Čufar, K.: Seasonal dynamics of phloem and xylem formation in silver fir and Norway spruce as affected by drought, Russ. J. Plant Phyl., 55, 538-543, doi:10.1134/s102144370804016x, 2008. 
Grunewald, K., Scheithauer, J., Monget, J.-M., and Brown, D.: Characterisation of contemporary local climate change in the mountains of southwest Bulgaria, Climatic Change, 95, 535549, doi:10.1007/s10584-008-9508-8, 2009.

Hafner, P., Robertson, I., McCarroll, D., Loader, N., Gagen, M., Bale, R., Jungner, H., Sonninen, E., Hilasvuori, E., and Levanič, T.: Climate signals in the ring widths and stable carbon, hydrogen and oxygen isotopic composition of Larix decidua; growing at the forest limit in the southeastern European Alps, Trees-Struct. Funct., 25, 1141-1154, doi:10.1007/s00468-011-0589-z, 2011.

Handler, P.: The effect of volcanic aerosols on global climate, J. Volcanol. Geoth. Res., 37, 233-249, doi:10.1016/03770273(89)90081-4, 1989.

Hughes, M. K., Kuniholm, P. I., Eischeid, J. K., Garfin, G., Griggs, C. B., and Latini, C.: Aegean tree-ring signature years explained, Tree-Ring Res., 57, 67-73, 2001.

Hughes, P. D.: Little Ice Age glaciers in the Balkans: low altitude glaciation enabled by cooler temperatures and local topoclimatic controls, Earth Surf. Proc. Land., 35, 229-241, doi:10.1002/esp.1916, 2010.

IPCC: IPCC 2001: Climate change 2001: the scientific basis. Contribution of working group 1 to the third assessment report of the intergovernmental panel on climate change, Cambridge University Press, Cambridge, New York, 881, 2001.

IPCC: Climate Change 2007: The physical science basis. Contribution of working group I to the fourth assessment report of the intergovernmental panel on climate change, edited by: Solomon, S., Qin, D., Manning, M., Chen, Z., Marquis, M., Averyt, K. B., Tignor, M., and Miller, H. L., Cambridge University Press, Cambridge, United Kingdom and New York, NY, USA, 996 pp., 2007.

Jones, P. D., Briffa, K. R., Barnett, T. P., and Tett, S. F. B.: Highresolution palaeoclimatic records for the last millennium: interpretation, integration and comparison with General Circulation Model control-run temperatures, Holocene, 8, 455-471, doi:10.1191/095968398667194956, 1998.

Jyske, T., Manner, M., Mäkinen, H., Nöjd, P., Peltola, H., and Repo, T.: The effects of artificial soil frost on cambial activity and xylem formation in Norway spruce, Trees, 26, 405-419, doi:10.1007/s00468-011-0601-7, 2012.

Kanji, G. K.: 100 statistical tests, Sage, London, 1993.

Kertész, Á. and Mika, J.: Aridification - Climate change in South-Eastern Europe, Phys. Chem. Earth Pt. A, 24, 913-920, doi:10.1016/s1464-1895(99)00135-0, 1999.

Koleva, E. and Alexandrov, V.: Drought in the Bulgarian low regions during the 20th century, Theor. Appl. Climatol., 92, 113120, doi:10.1007/s00704-007-0297-1, 2008.

Kostopoulou, E. and Jones, P. D.: Comprehensive analysis of the climate variability in the eastern Mediterranean. Part I: map-pattern classification, Int. J. Climatol., 27, 1189-1214, doi:10.1002/joc.1467, 2007.

Kuniholm, P. I. and Striker, C. L.: Dendrochronological Investigations in the Aegean and Neighboring Regions, 1977-1982, J. Field Archaeol., 10, 411-420, 1983.

Leal, S., Eamus, D., Grabner, M., Wimmer, R., and Cherubini, P.: Tree rings of Pinus nigra from the Vienna basin region (Austria) show evidence of change in climatic sensitivity in the late 20th century, Can. J. Forest Res., 38, 744-759, doi:10.1139/x07-189, 2008.
Lebourgeois, F.: Climatic signals in earlywood, latewood and total ring width of Corsican pine from western France, Ann. For. Sci., 57, 155-164, 2000.

Lelieveld, J., Hadjinicolaou, P., Kostopoulou, E., Chenoweth, J., El Maayar, M., Giannakopoulos, C., Hannides, C., Lange, M., Tanarhte, M., Tyrlis, E., and Xoplaki, E.: Climate change and impacts in the Eastern Mediterranean and the Middle East, Climatic Change, 114, 667-687, doi:10.1007/s10584-012-0418-4, 2012.

Levanič, T. and Toromani, E.: Austrian pine (Pinus nigra Arnold.) tree-ring width chronology from northeast Albania-preliminary results, TRACE, Otočec, Slovenia, 2010.

Levanič, T., Popa, I., Poljanšek, S., and Nechita, C.: A 323-year long reconstruction of drought for SW Romania based on black pine (Pinus nigra) tree-ring widths, Int. J. Biometeorol., Online ISSN: 1432-1254, 1-12, doi:10.1007/s00484-012-0596-9, 2012.

Lindgrén, S. and Neumann, J.: The cold and wet year 1695 - a contemporary German account, Climatic Change, 3, 173-187, doi:10.1007/bf00154435, 1981.

Ljungqvist, F. C.: A new reconstruction of temperature variability in the extra-tropical northern hemisphere during the last two millennia, Geogr. Ann. A, 92, 339-351, doi:10.1111/j.14680459.2010.00399.x, 2010.

López-Moreno, J. I., Vicente-Serrano, S. M., Morán-Tejeda, E., Lorenzo-Lacruz, J., Zabalza, J., Kenawy, A. E., and Beniston, M.: Influence of Winter North Atlantic Oscillation Index (NAO) on Climate and Snow Accumulation in the Mediterranean Mountains, in: Hydrological, Socioeconomic and Ecological Impacts of the North Atlantic Oscillation in the Mediterranean Region, edited by: Vicente-Serrano, S. M. and Trigo, R. M., Advances in Global Change Research, Springer Netherlands, 73-89, 2011.

Luterbacher, J., Rickli, R., Tinguely, C., Xoplaki, E., Schüpbach, E., Dietrich, D., Hüsler, J., Ambühl, M., Pfister, C., Beeli, P., Dietrich, U., Dannecker, A., Davies, T. D., Jones, P. D., Slonosky, V., Ogilvie, A. E. J., Maheras, P., Kolyva-Machera, F., Martin-Vide, J., Barriendos, M., Alcoforado, M. J., Nunes, M. F., Jónsson, T., Glaser, R., Jacobeit, J., Beck, C., Philipp, A., Beyer, U., Kaas, E., Schmith, T., Bärring, L., Jönsson, P., Rácz, L., and Wanner, H.: Monthly mean pressure reconstruction for the Late Maunder Minimum Period (AD 16751715), Int. J. Climatol., 20, 1049-1066, doi:10.1002/10970088(200008)20:10<1049::aid-joc521>3.0.co;2-6, 2000.

Luterbacher, J., Rickli, R., Xoplaki, E., Tinguely, C., Beck, C., Pfister, C., and Wanner, H.: The Late Maunder Minimum (16751715) - A Key Period for Studying Decadal Scale Climatic Change in Europe, Climatic Change, 49, 441-462, 2001.

Luterbacher, J., Dietrich, D., Xoplaki, E., Grosjean, M., and Wanner, H.: European Seasonal and Annual Temperature Variability, Trends, and Extremes Since 1500, Science, 303, 1499-1503, doi:10.1126/science.1093877, 2004.

Luterbacher, J., García-Herrera, R., Akcer-On, S., Allan, R., Alvarez-Castro, M.-C., Benito, G., Booth, J., Büntgen, U., Cagatay, N., Colombaroli, D., Davis, B., Esper, J., Felis, T., Fleitmann, D., Frank, D., Gallego, D., Garcia-Bustamante, E., Glaser, R., Gonzalez-Rouco, F. J., Goosse, H., Kiefer, T., Macklin, M. G., Manning, S. W., Montagna, P., Newman, L., Power, M. J., Rath, V., Ribera, P., Riemann, D., Roberts, N., Sicre, M.-A., Silenzi, S., Tinner, W., Tzedakis, P. C., Valero-Garcés, B., van der Schrier, G., Vannière, B., Vogt, S., Wanner, H., Werner, J. 
P., Willett, G., Williams, M. H., Xoplaki, E., Zerefos, C. S., and Zorita, E.: 2 - A Review of 2000 Years of Paleoclimatic Evidence in the Mediterranean, in: The Climate of the Mediterranean Region, edited by: Lionello, P., Elsevier, Oxford, 87-185, 2012.

Mariotti, A. and Dell' Aquila, A.: Decadal climate variability in the Mediterranean region: roles of large-scale forcings and regional processes, Clim. Dynam., 38, 1129-1145, 2012.

Martín-Benito, D., del Río, M., and Cañellas, I.: Black pine ( $P i$ nus nigra Arn.) growth divergence along a latitudinal gradient in Western Mediterranean mountains, Ann. For. Sci., 67, p. 401, doi:10.1051/forest/2009121, 2010a.

Martín-Benito, D., Del Río, M., Heinrich, I., Helle, G., and Cañellas, I.: Response of climate-growth relationships and water use efficiency to thinning in a Pinus nigra afforestation, Forest Ecol. Manag., 259, 967-975, doi:10.1016/j.foreco.2009.12.001, 2010b.

Martín-Benito, D., Kint, V., del Río, M., Muys, B., and Cañellas, I.: Growth responses of West-Mediterranean Pinus nigra to climate change are modulated by competition and productivity: Past trends and future perspectives, Forest Ecol. Manag., 262, 10301040, doi:10.1016/j.foreco.2011.05.038, 2011.

Martín-Benito, D., Beeckman, H., and Cañellas, I.: Influence of drought on tree rings and tracheid features of Pinus nigra and $\mathrm{Pi}$ nus sylvestris in a mesic Mediterranean forest, Eur. J. For. Res., Online ISSN: 1612-4677, 1-13, doi:10.1007/s10342-012-06523, 2012.

Mastin, L. G. and Witter, J. B.: The hazards of eruptions through lakes and seawater, J. Volcanol. Geoth. Res., 97, 195-214, doi:10.1016/s0377-0273(99)00174-2, 2000.

McCarroll, D., Jalkanen, R., Hicks, S., Tuovinen, M., Gagen, M., Pawellek, F., Eckstein, D., Schmitt, U., Autio, J., and Heikkinen, O.: Multiproxy dendroclimatology: a pilot study in northern Finland, Holocene, 13, 829-838, doi:10.1191/0959683603hl668rp, 2003.

McCarroll, D., Loader, N. J., Jalkanen, R., Gagen, M. H., Grudd, H., Gunnarson, B. E., Kirchhefer, A. J., Friedrich, M., Linderholm, H. W., Lindholm, M., Boettger, T., Los, S. O., Remmele, S., Kononov, Y. M., Yamazaki, Y. H., Young, G. H. F., and Zorita, E.: A 1200-year multi-proxy record of tree growth and summer temperature at the northern pine forest limit of Europe, Holocene, in press, 2013.

Meehl, G. A. and Tebaldi, C.: More Intense, More Frequent, and Longer Lasting Heat Waves in the 21st Century, Science, 305, 994-997, doi:10.1126/science.1098704, 2004.

Moosmüller, H., Chakrabarty, R. K., and Arnott, W. P.: Aerosol light absorption and its measurement: A review, J. Quant. Spectrosc. Ra., 110, 844-878, doi:10.1016/j.jqsrt.2009.02.035, 2009.

Nicault, A., Alleaume, S., Brewer, S., Carrer, M., Nola, P., and Guiot, J.: Mediterranean drought fluctuation during the last 500 years based on tree-ring data, Clim. Dynam., 31, 227-245, doi:10.1007/s00382-007-0349-3, 2008.

Niedźwiedź, T.: Climate, in: Recent Landform Evolution, edited by: Lóczy, D., Stankoviansky, M., and Kotarba, A., Springer Geography, Springer Netherlands, 19-29, 2012.

Ogrin, D.: Dry and wet years in Submediterranean Slovenia from the 14th to the mid-19th century, Acta Univ. Palacki. Olomuc., Fac. Rerum Nat., Geogr., 37, 8-11, 2002.

Ogrin, D.: Tree rings and climate in submediterranean Slovenia, TRACE 2005, 2005.
Panayotov, M., Bebi, P., Trouet, V., and Yurukov, S.: Climate signal in tree-ring chronologies of Pinus peuce and Pinus heldreichii; from the Pirin Mountains in Bulgaria, Trees-Struct. Funct., 24, 479-490, doi:10.1007/s00468-010-0416-y, 2010.

Penuelas, J. and Pilella, I.: Deuterium labelling of roots provides evidence of deep water access and hydraulic lift by Pinus nigra in a Mediterranean forest of NE Spain, Environ. Exp. Bot., 49, 201-208, doi:10.1016/S0098-8472(02)00070-9, 2003.

Poljanšek, S., Ballian, D., Nagel, T. A., and Levanič, T.: A 435Year-Long European Black Pine (Pinus nigra) Chronology for the Central-Western Balkan Region, Tree-Ring Res., 68, 31-44, doi:10.3959/2011-7.1, 2012.

Popa, I. and Kern, Z.: Long-term summer temperature reconstruction inferred from tree-ring records from the Eastern Carpathians, Clim. Dynam., 32, 1107-1117, doi:10.1007/s00382-0080439-x, 2009.

Rampino, M. R. and Self, S.: Historic eruptions of Tambora (1815), Krakatau (1883), and Agung (1963), their stratospheric aerosols, and climatic impact, Quaternary Res., 18, 127-143, doi:10.1016/0033-5894(82)90065-5, 1982.

Rossi, S., Deslauriers, A., Anfodillo, T., and Carraro, V.: Evidence of threshold temperatures for xylogenesis in conifers at high altitudes, Oecologia, 152, 1-12, doi:10.1007/s00442-006-0625-7, 2007.

Satheesh, S. K. and Krishna Moorthy, K.: Radiative effects of natural aerosols: A review, Atmos. Environ., 39, 2089-2110, doi:10.1016/j.atmosenv.2004.12.029, 2005.

Scandone, R., Giacomelli, L., and Speranza, F. F.: Persistent activity and violent strombolian eruptions at Vesuvius between 1631 and 1944, J. Volcanol. Geoth. Res., 170, 167-180, doi:10.1016/j.jvolgeores.2007.09.014, 2008.

Seim, A., Treydte, K., Büntgen, U., Esper, J., Fonti, P., Haska, H., Herzig, F., Tegel, W., and Faust, D.: Exploring the potential of Pinus heldreichii Christ. for long-term climate reconstruction in Albania, TRACE, Otočec, Slovenia, 75-82, 2010.

Seim, A., Büntgen, U., Fonti, P., Haska, H., Herzig, F., Tegel, W., Trouet, V., and Treydte, K.: Climate sensitivity of a millenniumlong pine chronology from Albania, Clim. Res., 51, 217-228, doi:10.3354/cr01076, 2012.

Seneviratne, S. I., Corti, T., Davin, E. L., Hirschi, M., Jaeger, E. B., Lehner, I., Orlowsky, B., and Teuling, A. J.: Investigating soil moisture-climate interactions in a changing climate: A review, Earth-Sci. Rev., 99, 125-161, doi:10.1016/j.earscirev.2010.02.004, 2010.

Sevgi, O. and Akkemik, U.: A dendroecological study on Pinus nigra Arn. at different altitudes of northern slopes of Kazdaglari, Turkey, J. Environ. Biol., India, 28, 73-75, 2007.

Stahle, D. W., Cleaveland, M. K., and Cerveny, R. S.: Tree-ring reconstructed sunshine duration over central USA, Int. J. Climatol., 11, 285-295, doi:10.1002/joc.3370110305, 1991.

Strumia, G., Wimmer, R., and Grabner, M.: Dendroclimatic sensitivity of Pinus nigra Arnold in Austria, Dendrochronologia, 15, 129-137, 1997.

Suehrcke, H.: On the relationship between duration of sunshine and solar radiation on the earth's surface: Ångström's equation revisited, Sol. Energy, 68, 417-425, doi:10.1016/s0038092x(00)00004-9, 2000.

Touchan, R., Garfin, G. M., Meko, D. M., Funkhouser, G., Erkan, N., Hughes, M. K., and Wallin, B. S.: Preliminary reconstruc- 
tions of spring precipitation in southwestern Turkey from treering width, Int. J. Climatol., 23, 157-171, 2003.

Touchan, R., Xoplaki, E., Funkhouser, G., Luterbacher, J., Hughes, M. K., Erkan, N., Akkemik, U., and Stephan, J.: Reconstructions of spring/summer precipitation for the Eastern Mediterranean from tree-ring widths and its connection to large-scale atmospheric circulation, Clim. Dynam., 25, 75-98, 2005.

Touchan, R., Akkemik, Ü., Hughes, M. K., and Erkan, N.: May-June precipitation reconstruction of southwestern Anatolia, Turkey during the last 900 years from tree rings, Quaternary Res., 68, 196-202, doi:10.1016/j.yqres.2007.07.001, 2007.

Trachsel, M., Kamenik, C., Grosjean, M., McCarroll, D., Moberg, A., Brázdil, R., Büntgen, U., Dobrovolný, P., Esper, J., Frank, D. C., Friedrich, M., Glaser, R., Larocque-Tobler, I., Nicolussi, K., and Riemann, D.: Multi-archive summer temperature reconstruction for the European Alps, AD 1053-1996, Quaternary Sci. Rev., 46, 66-79, doi:10.1016/j.quascirev.2012.04.021, 2012.

Trouet, V., Panayotov, M., Ivanova, A., and Frank, D.: A pan-European summer teleconnection mode recorded by a new temperature reconstruction from the northeastern Mediterranean (ad 1768-2008), Holocene, 22, 887-898, doi:10.1177/0959683611434225, 2012.

van Oldenborgh, G. J.: KNMI Climate explorer, Koninklijk Netherlands Meteorologisch Institut (KNMI), 1999.

Vicente-Serrano, S. M. and López-Moreno, J. I.: Hydrological response to different time scales of climatological drought: an evaluation of the Standardized Precipitation Index in a mountainous Mediterranean basin, Hydrol. Earth Syst. Sci., 9, 523-533, doi:10.5194/hess-9-523-2005, 2005.

Vidaković, M.: Conifers: morphology and variation, Grafički zavod Hrvatske, Zagreb, 754 pp., 1991.

Waring, R. H., Whitehead, D., and Jarvis, P. G.: The contribution of stored water to transpiration in Scots pine, Plant Cell Environ., 2, 309-317, doi:10.1111/j.1365-3040.1979.tb00085.x, 1979.

Weitzenkamp, B., Schneider, C., Kilian, R., Spiecker, H., and Kahle, H. P.: Regional climate tree growth at Gran Campo Nevado, Chilean Patagonia, Geophys. Res. Abstr., 9, 2007.
Wigley, T. M. L., Briffa, K. R., and Jones, P. D.: On the average value of correlated time series, with applications in dendroclimatology and hydrometeorology, J. Clim. Appl. Meteorol., 23, 201-213, 1984.

Wimmer, R., Strumia, G., and Holawe, F.: Use of false rings in Austrian pine to reconstruct early growing season precipitation, Can. J. For. Res., 30, 1691-1697, 2000.

Winchester, L.: The abnormal weather of 1929, Geography, 15, 579-585, 1930.

Xoplaki, E., Maheras, P., and Luterbacher, J.: Variability of Climate in Meridional Balkans during the Periods 1675-1715 and 1780 1830 and its Impact on Human Life, Climatic Change, 48, 581615, doi:10.1023/a:1005616424463, 2001.

Xoplaki, E., González Rouco, J. F., Gyalistras, D., Luterbacher, J., Rickli, R., and Wanner, H.: Interannual summer air temperature variability over Greece and its connection to the large-scale atmospheric circulation and Mediterranean SSTs 1950-1999, Clim. Dynam., 20, 537-554, doi:10.1007/s00382-002-0291-3, 2003a.

Xoplaki, E., Gonzalez-Rouco, F. J., Luterbacher, J., and Wanner, H.: Mediterranean summer air temperature variability and its connection to the large-scale atmospheric circulation and SSTs, Clim. Dynam., 20, 723-739, 2003b.

Xoplaki, E., Luterbacher, J., and Gonzalez-Rouco, F. J.: Mediterranean summer temperature and winter precipitation, large-scale dynamics, trends, Il Nuovo Cimento, 29, 45-54, 2006.

Young, G. H. F., McCarroll, D., Loader, N. J., and Kirchhefer, A. J.: A 500-year record of summer near-ground solar radiation from tree-ring stable carbon isotopes, Holocene, 20, 315-324, doi:10.1177/0959683609351902, 2010.

Zupan Hajna, N.: Dinaric karst: Geography and geology, in: Encyclopedia of Caves, 2nd Edn., edited by: White, B. W. and Culver, C. D., Elsevier, Oxford, 2012. 